\title{
Complexity within the Venetia K01 NE Coherent Kimberlite Facies Association: Implications for Conduit Processes in Kimberlite Pipe Forming Eruptions
}

\author{
C.C. Medlin ${ }^{1}$ and M.A. Tait ${ }^{2}$ \\ ${ }^{1}$ De Beers Group Services, Group Exploration, Private Bag X01, Southdale, 2135, Republic of South \\ Africa. (cmedlin@debeersgroup.com Phone: +27113747868) ${ }^{2}$ De Beers Group Services, Mineral \\ Resource Management, Private Bag X01, Southdale, 2135, RSA
}

\begin{abstract}
Introduction:
The Venetia K01 kimberlite pipe is the largest within South Africa's Venetia Kimberlite Cluster. Open cast mining has excavated K01 to $240 \mathrm{~m}$ below surface, affording excellent opportunity to investigate the internal architecture of the pipe. This work combines pit mapping and core logging with petrography and geochemistry, to investigate a key lithofacies association from within K01, namely the K01 North East Coherent Kimberlite (CKNE).
\end{abstract}

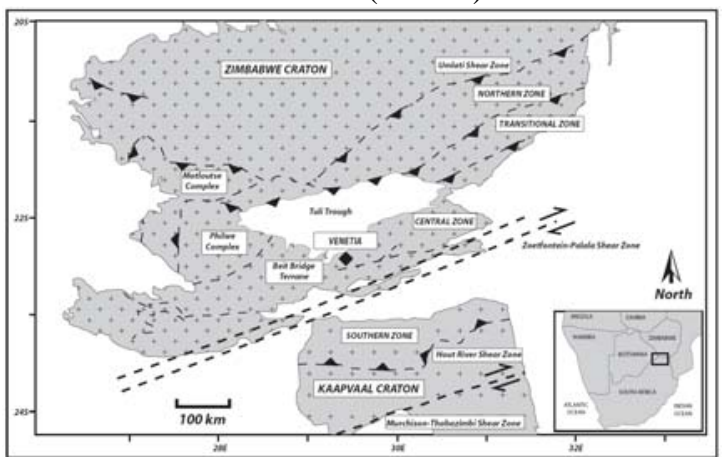

Figure 1: Regional Geological Setting of the Venetia Kimberlite Cluster (Modified from Barton et al., 2003).

\section{Geological Setting:}

The Venetia Kimberlite Field is situated within the Central Zone of the Proterozoic Limpopo mobile belt, South Africa, which forms an ancient collision zone between the Archaean Kaapvaal and Zimbabwe cratons (Figure 1, Barton et al., 2003). The $\sim 519+/-6$ Ma Venetia Kimberlite Cluster (Phillips et al., 1999) consists of a cluster of 15 pipes and dykes that outcrop over $\sim 4 \mathrm{~km}^{2}$ (Tait et al., 2006). The K01 kimberlite pipe had a pre-mining surface area of $\sim 12.7 \mathrm{Ha}$ and comprises 9 major lithofacies associations (Tait et al., 2006), dominated by numerous volcaniclastic facies (i.e. MVK, RVK, DVK) and 4 subordinate coherent kimberlites (CKW, CKS, CKN, CKNE), located on the western, southern, northern and north-eastern pipe margins respectively (Figure 2).

CKNE has a mapped surface area of $\sim 5600 \mathrm{~m}^{2}$ at current mining level and occupies the NE tip of the irregular, elongated eastern margin of K01 (Figure 2). Contacts with the surrounding country rock are extremely steep and sharp, with local evidence for shearing and alteration (serpentinisation and carbonatisation). The contact with the main pipe-filling facies (e.g. Massive Volcaniclastic Kimberlite) is more ambiguous and typically defined by a rapid (cm to mscale) gradation. This contact dips steeply towards the $\mathrm{N}-\mathrm{NE}$, therefore defining the body as conical in shape. Previous workers in the K01 pipe (Seggie et al., 1999; Kurszlaukis \& Barnett, 2003; Skinner \& Marsh, 2004; Tait et al., 2006) have described a complicated lithofacies association in the NE complex of K01 and have identified up to 5 textural variations, ranging from "transitional" kimberlite (Skinner \& Marsh, 2004) to varieties of "hypabyssal" and "segregationary" kimberlite (Seggie et al., 1999).

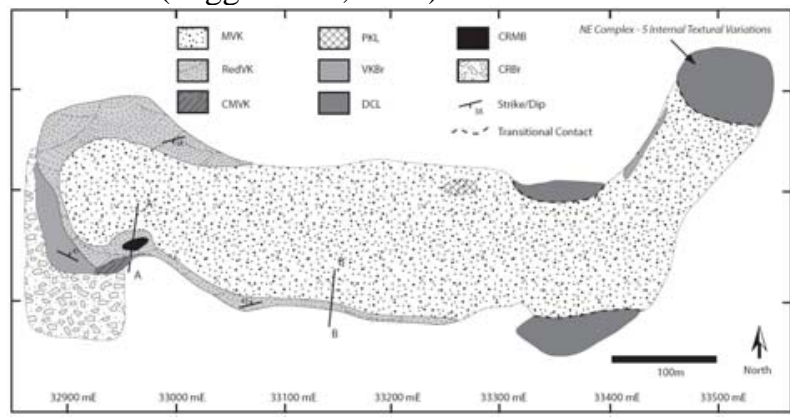

Figure 2: Simplified geological map of the K01 kimberlite, taken from Tait et al., (2006). The key focus of this study is the NE complex, marked in grey. Note the presence of a transitional contact between the main pipe fill and the CKNE complex.

\section{Geology of K01CKNE:}

Within the CKNE, up to five textural variations have been mapped, with internal contacts varying from gradational to sharp and possibly sheared. Textures vary from fragmental to ambiguous to coherent, with variations in crystal and lithic content observed. Broadly, the lithofacies association is described as a competent, grey to black kimberlite, comprising 30$50 \%$ serpentinised olivine crystals, with 5-25\% (highly) altered (carbonatised) lithic intraclasts. The matrix is dominated by calcite, serpentine and clay-rich material. Other crystal phases, including apatite, phlogopite, monticellite, spinel and other oxides are identified.

The focus of this study is a key textural variation identified within K01CKNE that can be described as a magmaclastic kimberlite (MCK; Field and Scott-Smith, 1998). The rock is grey in colour, hard, dense and 
massive (Figure 3), is inequigranular and appears fragmental in texture. Lithic clasts (dolerite, schist and abundant irresolvable white clasts) are heavily carbonatised ( 10-15 vol. \%, <100 mm) with fuzzy black reaction rims and vary from angular to subrounded. Olivine macro- and phenocrysts ( $\sim 50$ vol. \%, $<15 \mathrm{~mm}$ ) are brown in colour, serpentinised, randomly orientated, unevenly distributed, and vary from anhedral and rounded to sub-angular and broken. They are commonly rimmed by magnetite and locally, have been completely replaced by oxides. Clustering of crystals and lithics, and local matrix rich domains define the inequigranular texture that typifies this unit.

The rock matrix comprises fine-grained oxides, finegrained calcite plates, bleached fine-grained phlogopite, and very fine-grained microlitic apatite laths. The base comprises colourless carbonate, yellow to colourless serpentine and patchy irresolvable, brown-grey, clay-altered material. Locally the carbonate forms patches and pools between framework grains.

The distinctive clasts that define this particular facies are discrete and comprise $\sim 20$ vol. \% of the unit (Figure 3). A clearly defined contact is identified at most clast-host boundaries that is generally marked by a fine clay altered rim and a notable increase in oxide crystals. In most cases a tiny calcite vein can also be seen running along the clast boundary. The clasts themselves are characterised by a central core of a crystal or lithic fragment, around which a variably thick coating is identified, but clasts without cores are also identified. The clasts are spheroidal to ellipsoidal in geometry and range in size from $<5 \mathrm{~mm}$ to $61 \mathrm{~mm}$, with two distinct populations observed at $\sim 9 \mathrm{~mm}$ (simple, single coated clasts) and $\sim 20 \mathrm{~mm}$ (complex, multiple coated clasts). We have termed the latter as spherical, multi-shelled, cored, juvenile magmaclasts (Webb, 2006)

The material coating the clasts is described as coherent in texture and comprised of olivine phenocrysts that are predominantly subhedral to euhedral in habit. Anhedral crystals and rare broken fragments are also identified. Phenocrysts are generally concentrically aligned around the clast core, although some display random orientations (Figure 4). The olivine phenocrysts often increase in size and abundance, either toward the core or away from the core or have alternating size and distribution patterns. The intra-clast matrix is dominated by fine-grained euhedral oxides, carbonate pools \& plates, bleached very fine-grained phlogopite and microlitic laths of apatite. The base consists of clay-altered material, carbonate and serpentine. In some examples, multiple, concentric coatings (shells) have been observed. In these examples, distinct geochemical (see below) and petrographic differences are identified in each shell.
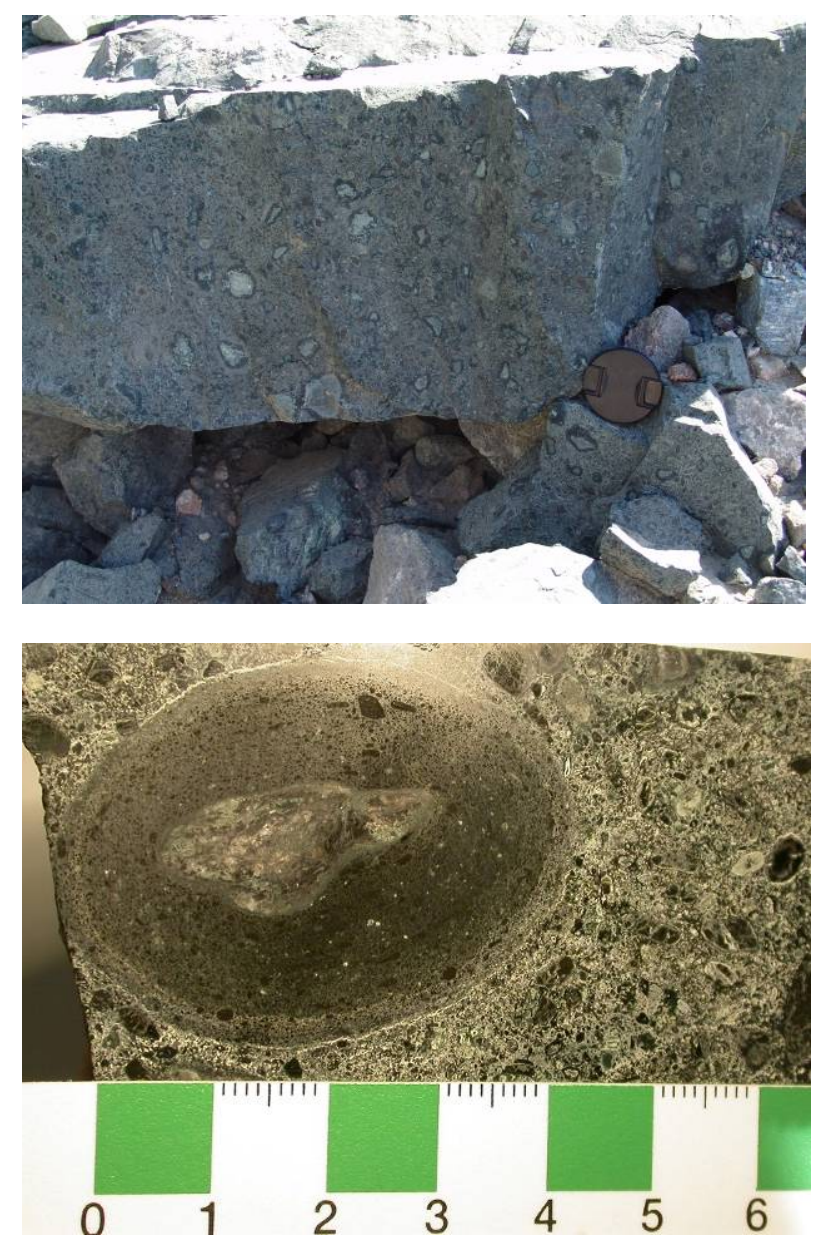

Figure 3: MCK Facies. 3a: Outcrop of unit. Note that many of the lithic clasts here have thick reaction rims, which are NOT juvenile clasts. 3b: An example of a juvenile lapillus from within the CKNE complex.

The magmaclastic kimberlite has been identified on the eastern margin of the complex, where a 5-7 metre thick domain is identified. The distinction used to discriminate this unit from the adjacent kimberlite facies in the field is the appearance of the characteristic discrete clasts and a paler colour than the surrounding dark grey to black kimberlite. The domain is bound by a sharp, intensely altered contact with the country rock to the east. A diffuse gradational contact with dark, coherent kimberlite is mapped to the west. Mapping at lower levels and logging of drill core from within this complex has failed to identify this textural variation at depth, although domains containing local coated clasts are identified. This suggests that this particular texture does not perpetuate to depths beneath the levels mapped by this work. It is unclear to what vertical height this unit extended to above the mapped levels.

Detailed microscopic analysis of the adjacent coherent kimberlite identified rare probable coated clasts, similar in nature to those clasts described here, consistent with the description of a gradational relationship between these internal textural variations and suggesting a close genetic relationship between them. 


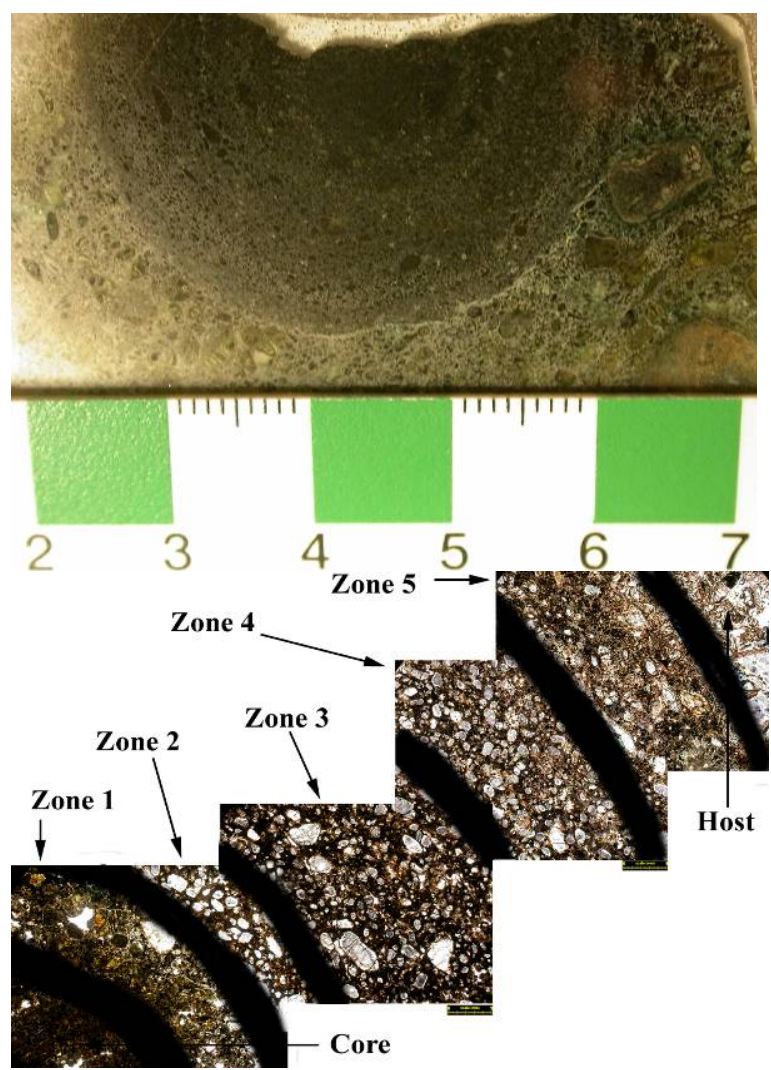

Figure 4: An example of a multi-shelled juvenile clast. 4a: One of the juvenile clasts used for geochemical analysis. 4b: Photomicrographs of a multi-shelled coated clast. The marked black lines define internal layers.

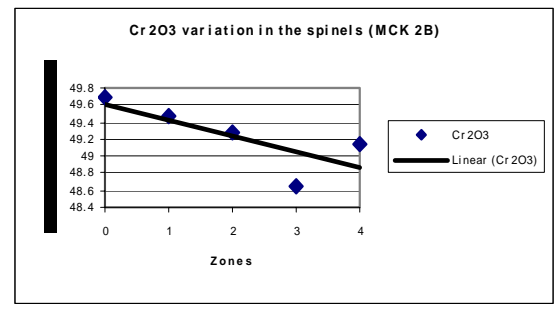

Figure 5: Spinel Mineral Chemistry Plot. Cr2O3\%. X axis bins define discrete zones from within multi shelled clasts (e.g. Figure 4b).

The three most representative polished thin sections of this unit were selected for microprobe analysis of groundmass spinels from within inter- and intra-clast matrices. Approximately fifty spinels from each thin section were analysed. Complex, multi-shelled clasts were selected and the concentric layers identified during petrographic work were marked, creating zones within each lapillus (Figure 4). Approximately ten randomly selected spinels were analysed from each zone. As is shown in Figure 5, chemical differences are recognised in spinel grains from within different zones of each of the clasts analysed. Similar differences are also recognised between spinel grains from the interand intra-clast domains.

\section{Discussion and Interpretations}

The results presented above indicate that the magmaclastic facies is fragmental, with the juvenile clasts most likely being formed due to dynamic volcaniclastic processes. The geometry and crystal arrangement within the juvenile coatings of the clasts, is consistent with a formation process whereby a core fragment/nuclei is rotated, while juvenile magma accretes and agglutinates around this nuclei, due to centrifugal forces, surface tension, magma quenching and liquid loss during explosive conduit processes (Stoppa, 1996; Junqueira-Brod et al., 1999). Based on petrographic and statistical mineral chemistry discrimination, it is possible to identify and confirm multiple distinct shells around individual clasts, which implies that these clasts interacted with different phases of erupting kimberlite magma, suggesting a dynamic and multi-phased emplacement history. As similar textures (e.g. spinning droplets) have been recognised in other volcanic systems (e.g. kamafugites and carbonatites; Junqueira-Brod et al., 1999), these observations have implications for our understanding of general conduit and magma fragmentation processes which occur in kimberlitic conditions. The clearly fragmental nature of this facies and the apparently gradational relationship with other textural variations within CKNE is indicative of a complex association produced by predominantly pyroclastic processes and not by emplacement of a high level intrusion.

\section{References}

Barton, J.M., Barnett, W.P., Barton, E.S., Barnett, M., Doorgapershad, A., Twiggs, C., Klemd, R., Martin, J., Mellonig, L. and Zenglein R. (2003). The geology of the area surrounding the Venetia kimberlite pipes, Limpopo Belt, South Africa. S. Afr. J. Geol. 106, pp. 109-128.

Field, M. and Scott Smith, B.H. (1998). Textural and genetic classification schemes for kimberlites: a new perspective. $7^{\text {th }}$ IKC, Cape Town, Extended Abstracts, pp 214-216.

Junqueira-Brod, T.C., Brod, J.A., Thompson, R.N. and Gibson S.A. (1999). Spinning droplets: a conspicuous lapilli-size structure in kamafugitic diatremes of Southern Goiás. Revista Brasileira de Geociencias, 29, pp. 437440.

Kurszlaukis, S., Barnett W., (2003). Volcanological and structural aspects of the Venetia Kimberlite Cluster. $S$. Afr. J. Geol., 106:165-192

Philips, D., Kiviets, G.B., Barton, E.S., Smith, C.B., Viljoen, K.S. and Fourie, L.F. (1999). ${ }^{40} \mathrm{Ar} /{ }^{39} \mathrm{Ar}$ dating of the kimberlites and related rocks: problems and solution. $7^{\text {th }}$ IKC, Cape Town, 1998. pp. 677-687.

Seggie, A.G., Hannweg, G.W., Colgan, E.A. Smith C.B. (1999). The geology and geochemistry of the Venetia kimberlite cluster, Northern Province, South Africa. $7^{\text {th }}$ IKC, Cape Town, 1998, pp. 750-756.

Skinner, E.M.W., Marsh, J.S., (2004). Distinct kimberlite classes with contrasting eruption processes. Lithos, $76: 183-200$

Stoppa, F. (1996). The San Venanzo maar and tuff ring, Umbria, Italy: eruptive behaviour of a carbonatitemelilitite volcano. Bull. Volc. 57:563-577.

Tait, M.A., Brown, R.J., Mnyama, A., (2006). Internal Architecture of the Venetia K1 Kimberlite. Venetia Mine, Limpopo RSA. Kimberlite emplacement Workshop Long Abstract, Saskatoon, Canada.

Webb, K.J. (2006). Juvenile clasts in kimberlites: Standardised comprehensive description towards unravelling emplacement mechanisms. Kimberlite emplacement Workshop Long Abstract, Saskatoon, Canada. 